\title{
CHANGES IN CARDIAC RESPONSES OF SPORTSMEN FROM HOURS OF PROLONGED SEVERE EXERCISE
}

\author{
J. D. BROOKE, Ph.D., M.Sc. \\ Lecturer in Physical Education, Human Performance Laboratory, University of Salford. \\ M. FIRTH, B.C.F. Senior Coach
}

\begin{abstract}
Resting heart rates were obtained hours before and after severe physical exercise performed by racing cyclists on the Tour of the North (Ireland) 1971. With long duration of performance there was elevation of heart rates for up to seven hours post activity, when compared with morning values or with similarly timed post activity measures following short duration performance. Attention is directed to the possible implication of body heat retention or disturbed body water-electrolytes homeostasis. Also noted is the affect of the phenomenon upon the use of resting heart rates for fitness assessment.
\end{abstract}

\section{Introduction}

An index of fitness frequently referred to is the resting heart rate. It might be expected that in addition to the general level of fitness this resting heart rate would also be affected by the daily exercise regime. If this is the case the two effects will interact and necessitate partialling out or standardisation if one, such as the general level of fitness, is being studied. The present paper reports on the results obtained from sportsmen carrying out severe physical work over hours, a team of four racing cyclists taking part in the five-day Tour of the North (Ireland) 1971.

\section{The Problem}

The problem was to study the difference in 'resting' heart rates, pre and post daily severe exercise of differing duration.

\section{Method}

The heart rates of four subjects, constituting the BCF Manchester Division Team in the 1971 five-day Tour of the North (Ireland) cycle race, were measured by radial palpation for ten beats, after Brooke, Hamley and Thomason (1970), using the Huer Pulsation Timer Model 403.229, over the three days in the central period of the Tour, as shown in Fig. 1.* The Fig. indicates that the measures, termed 'resting' as against exercise or basal rates, were obtained at $8-00$ a.m. each morning (approximately 3 hours before the start of the race) and, in the evening, approximately 4 hours and 7 hours post race. Subjects sat quietly for 5 minutes prior to the measurements.

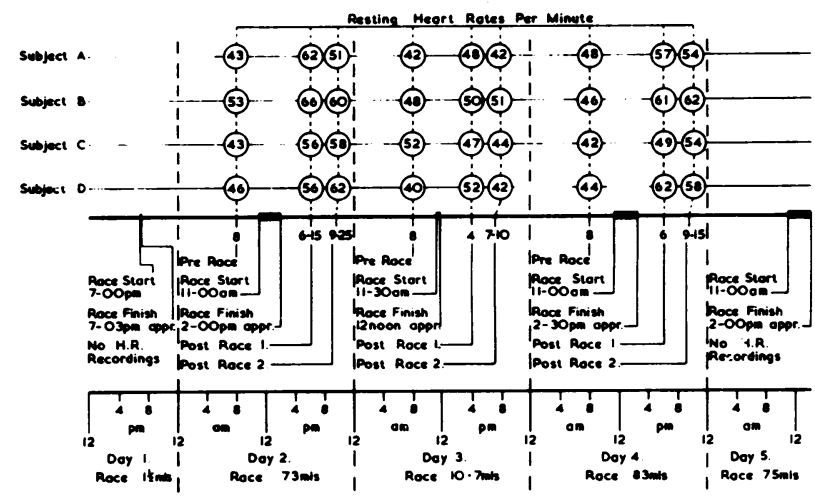

Fig. 1: Race and Heart Rate Measure Time Schedule.

The relationship of the heart rate per minute palpation procedure to the heart rate per minute calculated from ten $\mathbf{R}-\mathbf{R}$ waves by direct wire electrocardiography is shown in Table 1 for one subject. The difference of only one beat per minute between the two methods indicates the validity of the use of palpation for this level of heart rate.

\begin{tabular}{|c|c|c|c|}
\hline Assessment & $\begin{array}{c}\text { ECg } \\
\text { Beots Min }\end{array}$ & $\begin{array}{c}\text { Polpotion } \\
\text { Beots Min }\end{array}$ & Deviotion \\
\hline 1 & 52 & 51 & 1 \\
2 & 57 & 56 & 1 \\
3 & 68 & 67 & 1 \\
4 & 51 & 50 & 1 \\
5 & 54 & 53 & 1 \\
\hline & & & $\bar{x}=1$ \\
& & & $3=0$ \\
\hline
\end{tabular}

Toble 1: Comporison of Radial Palpotion with Chronograph vs Direct Wire Ecg Meosurement of Heort Rote
per Minute from Time for 10 Beots $(n=1)$

On the second day of the Tour the race was over 73 miles, being approximately 3 hours severe effort. On the third day only 10.7 miles were covered in an individual time trial, taking approximately 25 minutes. The fourth day consisted of a race over 83 miles, approximately 3.5 hours duration. The comparative average speeds for the four riders over the three days were $24.17 \mathrm{~m} . \mathrm{p} . \mathrm{h}$. (Subject A), 23.95 m.p.h. (Subject B), 23.81 m.p.h. (Subject C) and 23.74 m.p.h. (Subject D). Weather conditions throughout were dry, warm and sunny; daily temperatures during the time the race was in progress

* The assistance of Mr. H. Nelson in collecting data is acknowledged gratefully. 
were between 55 degrees Fahrenheit and 65 degrees Fahrenheit. Wind force was Scale 2 (Beaufort Scale) and was variable in direction. Relative humidity during the period of the race was between $50 \%$ and $70 \%$.

The data was analysed by analysis of variance with Scheffe's procedure for comparing means, to test statistically the difference between the mean of (4 subjects) pre-race and mean 1st post-race resting heart rates for each of the three days in one analysis, and the difference between the mean pre-race and mean 2nd post-race resting heart rates for each of the three days in the second analysis.

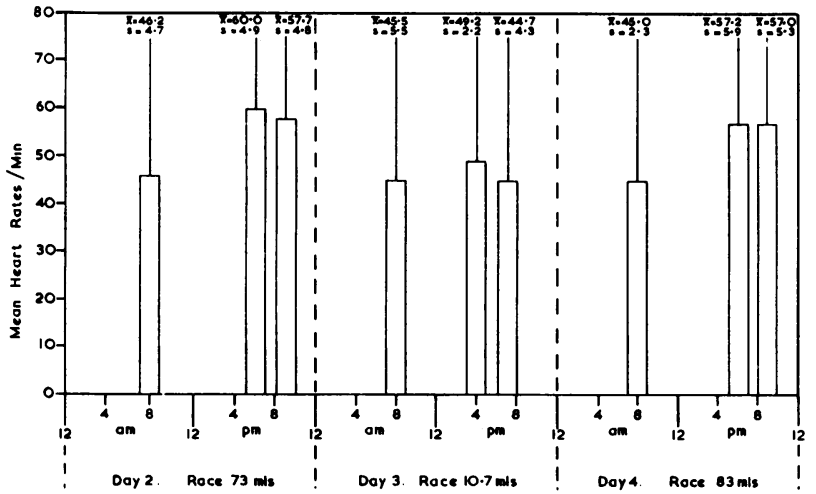

Fig. 2: Mean Heart Rates/Min. Pre, and 4 hrs. and 7 hrs. Post Race Over Three Days of Differing Race Duration ( $n=4)$.

\section{Results}

Fig. 2 shows the means and standard deviations for the heart rates per minute pre-race and 4 hours and 7 hours post-race over the three days of differing race duration. As shown in Table 2, the apparent differences to be seen in Fig. 1, between the pre and both post-race heart rates for days 2 and 4 , were statistically significant $(p=0.05)$. The difference between pre and post-race

\begin{tabular}{|c|c|c|c|c|c|}
\hline Doy & $\begin{array}{l}\text { Roce } \\
\text { Dist. }\end{array}$ & $\begin{array}{l}\text { Comporison of } \\
\text { Mean Heort Rotes/Min }\end{array}$ & $\begin{array}{c}\text { Mine } \\
\text { After } \\
\text { Roce } \\
\text { Finish }\end{array}$ & F Rotio & $\begin{array}{l}\text { Sig. } \\
\text { Level }\end{array}$ \\
\hline 2 & $73 \mathrm{mls}$ & $\begin{array}{l}\text { Pre Roce vs lst Post Roce } \\
\text { 2nd Post Roce }\end{array}$ & $\begin{array}{l}4 \cdot 25 \mathrm{hrs} \\
7 \cdot 41 \mathrm{hrs}\end{array}$ & $\begin{array}{l}18 \cdot 43 \\
13 \cdot 79\end{array}$ & $\begin{array}{l}0.05 \\
0.05\end{array}$ \\
\hline 3 & $10.7 \mathrm{~m} / \mathrm{s}$ & Pre Roce vs Ist Post Roce & $\begin{array}{l}4.00 \mathrm{hrs} \\
7.16 \mathrm{hrs}\end{array}$ & $\begin{array}{l}1 \cdot 37 \\
0.06\end{array}$ & $\begin{array}{l}\text { N.S. } \\
\text { N.S. }\end{array}$ \\
\hline 4 & $83 \mathrm{~m} / \mathrm{s}$ & $\begin{array}{l}\text { Ist Post Roce } \\
\text { 2nd Post Roce }\end{array}$ & $\begin{array}{l}\text { 3.50hrs } \\
6.75 \mathrm{hrs}\end{array}$ & $\begin{array}{l}14.63 \\
15.02\end{array}$ & $\begin{array}{l}0.05 \\
0.05\end{array}$ \\
\hline $\begin{array}{c}2 \\
v 3 \\
3\end{array}$ & & $\begin{array}{l}\text { Ist Post Roce vs lat Post Roce } \\
\text { 2nd Post Roce vs 2nd Post Roce }\end{array}$ & & $\begin{array}{l}11 \cdot 27 \\
17.62\end{array}$ & $\begin{array}{l}0.10 \\
0.05\end{array}$ \\
\hline $\begin{array}{c}3 \\
\text { vs } \\
4\end{array}$ & & $\begin{array}{l}\text { Ist Post Roce vs last Post Roce } \\
\text { 2nd Post Roce vs 2nd Post Roce }\end{array}$ & & $\begin{array}{r}6 \cdot 24 \\
15 \cdot 65 \\
\end{array}$ & $\begin{array}{l}0.10 \\
0.05\end{array}$ \\
\hline $\begin{array}{c}2 \\
\text { vs } \\
4\end{array}$ & & $\begin{array}{l}\text { Ist Post Roce vs Ist Post Roce } \\
\text { 2ndPost Roce vs 2nd Post Roce }\end{array}$ & & $\begin{array}{l}0.74 \\
0.06\end{array}$ & $\begin{array}{l}\text { N.S. } \\
\text { N.S. }\end{array}$ \\
\hline
\end{tabular}

Toble 2: Differences Between Meon Heort Rotes per Minute Pre and Post Roces of Differing Durotion Compored by Scheffe's Procedure ond Anolysis of Voriance. recordings for day 3 with this number of subjects was not significant at $p=0.05$ or $p=0.10$. Testing at $p=$ 0.10 as recommended by Scheffé revealed significant differences between the 1st post-race results for days 2 vs. 3 and days 4 vs. 3 , but not for days 2 vs. 4 . For these comparisons at the 2 nd post-race level the significant differences remained but increased to the $p=0.05$ level of probability.

\section{Discussion}

The results demonstrate that hard sustained exercise over hours for the heart rate leads to an elevation which can be observed up to 7 hours after the activity. When exercise of similar intensity but of approximately 25 minutes duration is taken, the post exercise heart rate at such times cannot be differentiated from the early morning pre-exercise heart rate.

It does not appear that this effect is due to the cessation of the short duration exercise earlier in the day, for at the first post-exercise check, 4 hours after the short duration exercise, the heart rate has returned close to the early morning levels.

From the average speeds of racing, one would predict by extrapolation from Brooke and Davies (1972) that during the activity the heart rate of the subjects was in the range 180 - 195 beats/minute with energy expenditure approximately $62.79 \mathrm{kj} /$ minute. This indicates the intensity of work. In the short term exercise of the third day, physiological responses would be expected to exceed only a little these levels, the average speed for the four subjects on that day being approximately $25.08 \mathrm{~m} . \mathrm{p} . \mathrm{h}$. The intensity of work throughout was high. But it did not differentiate between the 'resting' heart rates hours after cessation of the work.

The statement is that the post-exercise elevation of heart rate hours after the cessation of hard work is due not to the intensity but to the duration of the activity. No information to throw light directly upon the aetiology of this phenomenon is available in the present research. Over 3.5 hours hard physical work severe depletion of the available carbohydrate stores probably occurred, as described by Hultman and Bergström (1967) and Brooke, Davies and Green (1972). With repeated depletion of these stores over successive days Costill et al (1971) demonstrated concomitant reduced levels of exercise heart rates but did not report post exercise resting heart rates. It is possible that the metabolic provision for the necessary. glycogen re-synthesis may be a causative factor in the elevated resting heart rate hours after the activity.

More promising is the hypothesis that disturbances of the body stores of water and electrolytes are affecting 
either the cardiac response directly or the peripheral circulatory demand on the body. Ahlborg et al (1967) report marked fall off in excretion of water, sodium, potassium and chloride in subjects exercising for 70 190 minutes with water intake of 1 litre, with a fall in skeletal muscle tissue potassium by $4 \%$ of basal value. It is clear that with sustained sub-maximal exercise there is a rise in plasma osmolarity, attributable to the shift of fluid from plasma into the interstitial space to maintain the interstitial fluid, as described by De Lanne et al (1959) and Cullumbine and Koch (1949). This has a direct effect upon the viscosity of the blood pumped by the heart. Schlant (1966) points out that this is of marked significance in increasing the resistance in small blood vessels, although their connection in parallel serves to moderate against the effect. The changes in the normal balance of both potassium and sodium ions have an effect also upon the contractility of muscle, vascular smooth, Jonsson (1969) and cardiac, Cherbakoff et al (1957). Thus the elevated heart rate hours after prolonged exercise might be attributable to disturbed water-electrolyte homeostasis affecting the metabolism of peripheral vascularization, skeletal musculature or the myocardium direct, e.g. Regan et al (1967) implicate potassium loss from myocardial cells in the iniation of cardiac arrythmias. Greenleaf and Castle (1971) have reported recently that hypohydration to $-5 \%$ of body weight results in exercise heart rates elevated above ad libitum fluid intake exercise rates, with the effect being noticeable to the degree of approximately 4 beats in the pre exercise heart rate. These differences are similar in magnitude and direction to those reported in the present research: the underlying bodily changes are multiple.

A further hypothesis for the elevated 'resting' heart rates after prolonged severe exercise is the effect of body temperature. The energy conversion of skeletal muscular activity involves a heat component, the dissipation of which is effected mainly by transport in the circulation to the skin. Accordingly linear relationships are reported for body temperature and heart rate, e.g. Christensen (1953) and Kamon and Belding (1971). The retention of body heat post exercise would result in elevated 'resting' heart rates. The effect is more possible with the present data, for the extended performance was into the hottest part of the day. However, the inadequacy of this hypothesis is similar to that for the previous one, i.e. the time elapsed since the homeostatic disturbances from the exercise. Up to eight hours post-exercise is a considerable duration for heat effects to be still apparent: such a time lag would be more compatible with inadequate electrolyte and water replacement.

It is not possible to pursue this problem further with the present data. Relevant information to clarify the problem may be found in the pattern of body temperature over hours following exercise and the pattern of dietary intake and subsequent water-electrolyte states, both in relation to the heart rate. For the present the results will affect the study of the fitness of subjects and indicate a need to explore changes in the exercise and postexercise diet of the sportsman.

\section{Conclusions}

1. With high intensity of physical work, long duration of performance elevated heart rates for up to seven hours post activity.

2. The aetiological possibilities are numerous, with preference directed to body heat dissipation and to the restoration of water and electrolytes homeostasis.

\section{REFERENCES}

1. AHLBORG, B., BERGSTRÖM, J., EKELUND, L. G. and HULTMAN, E. (1967). Muscle glycogen and muscle electrolytes during prolonged severe exercise. Acta Physiol. Scand. 70, 129-142.

2. BROOKE, J. D. and DAVIES, G. J. (1972). Comment on estimation of the energy expenditure of sporting cyclists. Ergonomics (In Press).

3. BROOKE, J. D., DAVIES, G. J. and GREEN, L. F. (1972). Nutrition during severe prolonged exercise in trained cyclists. Proc. Nutr. Soc. (In Press).

4. BROOKE, J. D., HAMLEY, E. J. and THOMASON, H. (1970). Variability in the measurement of exercise heart rate.J. Spt. Med. Phys. Fit. 10, 1, 21-26.

5. CHERBAKOFF, A., TOYAMA, S. and HAMILTON, W. F. (1957). Circulation. 5, 517.

6. CHRISTENSEN, E. H. (1953). Physiological valuation of work in Nykroppa iron works. In: W. F. Floyd and A. T. Welford (Eds.). Symposium on Fatigue, London: Lewis, 93-108. 
7. COSTILL, D. L., BOWERS, R., BRANAM, G. and SPARK, K. (1971). Muscle glycogen utilisation during prolonged exercise on successive days. J. Appl. Physiol. 31, 6, 834-838.

8. CULLUMBINE, H. and KOCH, A. C. E. (1949). The changes in plasma and tissue fluid volume following exercise. Quart. J. Exp. Physiol. 35, 39-46.

9. GREENLEAF, J. E. and CASTLE, B. L. (1971). Exercise temperature regulation in men during hypohydration and hyperhydration. J. Appl. Physiol. 30, 6, 847-853.

10. HULTMAN, E. and BERGSTRÖM, J. (1967). Muscle glycogen synthesis in relation to diet studied in normal subjects. Acta. Med. Scand. 182, 1, 109-117.

11. JONSSON, O. (1969). Changes in the activity of isolated vascular smooth muscle in response to reduced osmolarity. Acta. Physiol. Scand. 77, 191-200.

12. KAMON, E. and BELDING, H. S. (1971). Heart rate and rectal temperature relationships during work in hot humid environments. J. Appl. Physiol. 31, 3, 472-477.

13. DE LANNE, R., BARNES, J. R. and BROUHA, L. (1959). Changes in osmotic pressure and ionic concentrations of plasma during muscular work and recovery. J. Appl. Physiol. 14, 804-808.

14. REGAN, T. J., HARMAN, M. A., LEHAN, P. H., BURKE, W. M. and OLDEWURTEL, H. A. (1967). J. Clin. Invest. 46, 1657.

15. SCHLANT, R. C. (1966). Normal anatomy and function of the cardiovascular system. In: J. W. Hurst and R. B. Logue (Eds.). The Heart, London: McGraw-Hill. 16-41.

\section{REVIEW}

"Post-Graduate SPORTS MEDICINE SYMPOSIUM, held in co-operation with the IXth British Commonwealth Games Medical Committee, July 19th, 1970, Edinburgh"

Published by The Institute of Sports Medicine, no date given, (received February 1972)

pp23 Price $£ 1.85$

This folder consists of papers read at a Symposium in Edinburgh in 1970 and contains twenty-three pages, fourteen of which are excellently filled by Dr. Griffith Pugh on "The Gooseflesh Syndrome in Long Distance Runners". Lest it be thought that the extraordinary price of $£ 1.85$ be fair for this paper alone, a shorter version appeared in the British Journal of Physical Education, March 1972, and the definitive version is in press at present*. Dr. Durnin's talk on Physical Activity and the Fat Content of the Body has lost its point by reduction to a mere one page abstract. A preliminary communication on the Effect of Training on the Resting ECG's of Top Class Swimmers shows that athletes often have "abnormal" ECG's at rest. The three references given by Dr. Jenkins omit mention of earlier workers who have explored this phenomenon in greater detail; in swimmers; in Britain.

A final half-page synopsis of a talk on radiotelemetry is too brief to be really useful and omits any reference, either to previous workers, or to publications.

The astonishing remarks in the Editorial introduction about the novelty of the ECG findings, together with the introductory statement that the I.S.M. makes "no apologies for our concern with high academic attainment as a pre-requisite in the studies and research we sponsor", makes one restless to see the results of any further studies that the Institute may be sponsoring. For the record, Dr. Pugh's excellent work was sponsored by the British Olympic Association and the Medical Research Council.

*Reference - PUGH

P. N. SPERRYN, M.B., B.S., M.R.C.P., D.Phys.Med. 